\title{
PROBLEMS OF CODIFYING SECURITY LAW
}

\author{
K. N. LLEWELIYN* \\ I

\section{Why Codification?}

The first question in regard to any projected change in law must be: What need is there for change? In regard to secured commercial transactions, there is a wealth of recognized legal devices, traditional, established, familiar at least to the rather small selection of lawyers who have specialized in the field. There is the chattel mortgage, the conditional sale, the pledge of documents of title with its now rather well developed "field warehouse" variant; there is the trust receipt; there are the two rather different types of assignment of contract rights: that of accounts receivable in bloc and that of a single executory production contract; there is the bailment variation of the sale on installments, familiar especially in railroad equipment financing as "the Pennsylvania plan"; there is the true factor's (i.e., selling agent's) possessory lien, and the banker-"factor's" statutory lien on the New York model. There is the introduction of banker's responsibility for the price of goods by way of the letter of credit, there is the device of suretyship or guaranty, there is the discount of customers' acceptances or consumers' notes.

Such an array of accepted legal devices is imposing in variety and in proved adaptability. What more is needed? The answer runs in terms of seven ideas: clarity; simplicity, convenience, and fairness (which I shall discuss together); completeness, accessibility, and uniformity (which I shall again discuss together).

\section{A. Clarity}

There has been really amazing skill displayed by financing counsel in their adjustment of available legal concepts to the needs of commercial financing. Let me instance only the original development of "reservation of title" in documents as it moved out of the internal grain trade into the importing business in general and thence into such areas as the floor-planning finance of automobiles.

Yet the work of rebuilding old devices to take care of new needs is a work spotted all along its course with doubts which can be removed only one by one, and jurisdiction by jurisdiction; the penalty for any misguess on any point in any jurisdiction is deprivation of the intended security in the very event against which the transaction was planned to be secure. Thus, for example, today good lawyers be-

- Betts Professor of Jurisprudence, Columbia University. Chief Reporter in charge of the Uniform Commercial Code, under the auspices of the American Law Institute and the National Conference of Commissioners on Uniform State Laws. 
lieve (though I do not) that all trust receipt security is in peril or lost under the doctrine of the Klauder ${ }^{1}$ and Vardaman ${ }^{2}$ cases. Other good lawyers (of whom I claim to be one) believe the conflict-of-laws situation in the assignment of receivables of an interstate business to rest in practical uncertainty, depending in good part on the eventual particular facts and issue in hand and the skill in argument displayed by the respective counsel when the issue may finally come up. Any such doubt goes to the essence of security. In field warehousing, the question of how far physically and commercially unlike units can be standardized by agreement into interchangeable units-as is, for instance, desired in the grocery trade-is still open, with the indications running along the undesired line; nor are we really clear with regard to the solidity of warehouse receipts for bonded whiskey in the distiller's own warehouse. Neither as among the states nor state by state is it clear, under modern banking practice, when a banker who discounts a price draft against the bill of lading acquires the bona fide holder status which insulates him against claims for breach of the seller's contract, claims enforceable by attachment of the documents, goods, or proceeds. The problem of financing air shipments is still to be worked out. And the moral effect of Benedict v. Ratner ${ }^{3}$ can very well (though it is not "supposed to") carry over materially beyond the limits which Erie Railroad v. Tompkins (a decision which is losing something of its original unwise overmomentum) would seem to have imposed upon a "mere interpretation of the law of New York."

Such matters are minor, however numerous. They can doubtless be picked up one by one in little amendatory acts, and so cured, one by one. Yet they present a background which begins to hint at the need for further and more fundamental recanvass of the whole law of the field.

\section{B. Simplicity, Convenience, and Fairness}

What is not minor is the price in complexity, inconvenience, and often in unfairness which must be paid when legal patterns of happenstance origin are taken in all their history-ridden detail as the basis for the doing of remodeling jobs which are themselves piece-work. Adjustment to the needs of single situation after single situation can be and has been achieved by counsel; but the adjustment reminds one somewhat of the life history of an old New England farmhouse, added to, patched, rearranged, "modernized"-and still with no closets where closets are wanted, with the kitchen occupying the best prospect, with upstairs traffic clogged by corners and sudden shifts of level, with plumbing and heating "in," but unhappily cumbersome in placement, use, and repair.

Thus, for instance, if a state has adopted the Uniform Conditional Sales Act, the seller's foreclosure on a $\$ 40,000$ refrigerating plant in a brewery is hampered by provisions designed to protect the consumer who has bought a $\$ 400$ or $\$ 40$ domestic refrigerator; whereas if some version of the common law still prevails in the state,

1 3I 8 U. S. 434 (I943).

${ }_{268}$ U. S. 353 (1925).
${ }^{2}{ }_{52}$ F. Supp. 562 (E.D. Mo. 1943).

304 U. S. 64 (1938). 
the lines of foreclosure built by counsel (whether by way of conditional sale or of bailment-lease) to protect the lender in the case of the refrigerating plant are available equally in the domestic case, with frequent resulting hardship. Again, the purchase-money chattel mortgage is, on the publicity side, afflicted even in the case of a consumer-buyer with formalities and "safeguards" originally designed to hinder a businessman from himself hindering his general business creditors; but once the seller accepts that handicap, he has open to him (as in the cheap furniture business) an extension of his "purchase-money" security to cover any other assets which the buyer may possess, and that means hardship to many more consumers than is warranted by the sound business needs of the trade. Neither in regard to the business borrower ("inventory" security) nor in regard to the farmer or the consumer is there any over-all sense in regard to the divergent publicity requirements as among the various legal devices which provide security. Within the same state a conditional sale for resale or an assignment of accounts receivable may stand in secret on pure contract, a consignment require a sign on the premises, a statutory "factor's" lien require both a sign and a general-notice filing, a trust receipt require merely the latter but also successive specific identification by contract of the individual chattels covered, while a chattel mortgage will require not only to be specific in regard to the chattels covered but also to be recorded locally.

Now, if delay in legal service and long, detailed research and consequent need for peculiarly skilled counsel at appropriate fees for their skill and their time are a major purpose of law, then all one can say is that, with care and patience, this picture can easily be rendered even more complex and can be even further deprived of intelligible rationale; but if what law is for is speedy, effective, reliable service at a reasonable price, from any competent lawyer, whether to general creditors who need information, or to secured creditors who desire safe simplicity of operation, or to the borrowers who pay the overhead of the current explorations of the legal labyrinth, or to the consumers who ultimately in turn absorb those fees-then it is surely time to take a fresh look at the whole problem, in terms not of what kinds of device are historically given, but of what kinds of device are needed to get the jobs in question both done well and done more simply. One first sign of such a fresh look, indeed, has been the recognition that the material is not "property" material, but is "commercial," and that it belongs in a Commercial Code because it is financing which provides the sinews of commerce.

One point should be made before I proceed. Technicalities sometimes yield by-products of value. I shall be slow to be persuaded, for instance, that the Benedict $v$. Ratner ruling which made policing of proceeds a condition to legal validity of a mortgage on a stock in trade did not have a healthy influence on inventory financing, that that ruling did not materially contribute to developing such practices as the payment of proceeds into an ear-marked special account, indeed in general on the type of careful policing practice which, as Mr. Burman's paper shows, has earned a recognition for its business value in this freld which will per- 
sist even though such policing should cease to be a legal requisite to validity of the lender's lien.

\section{Completeness, Accessibility, and Uniformity}

Closely related to the question of convenience in use of the security devices is that of convenient access to the relevant rules of law. This has, of course, since the original NIL been one objective of the partial codifications in the commercial field. Its importance rises as the general body of law becomes more bulky, as is attested by the spread of the "family" type of statute, e.g. $r e$ bulk sales, trust receipts, statutory factors' liens, automobile certificates of title, and (though along two divergent lines) assignment of receivables. Yet much of the relevant law remains case law and slow to get at: thus the bulk of chattel-mortgage law, and in most states that of conditional sales and bailment-leases; and the statutes are very spotty on such vital phases of inventory finance as after-acquired assets, the lender's right to proceeds, or, with the statutory factors' lien, the procedures available on default. Again, in the essentially competing field of "open" long-term financing, few states provide for the convenient gearing of a mortgage on equipment to a mortgage on the plant or hotel of which the equipment is a necessary going part.

The various "uniform" statutes, moreover-quite apart from some emerging variances in their interpretation-have not only been presented for adoption one by one, with consequent variant groupings of adoptions in different states, but they were originally worked out one by one, with consequent clashes of theory and uncovered gaps. The idea of uniformity therefore bites, in this material, with a double force. It is not merely a question of having rules phrased and conveniently accessible, phrased and accessible in the same words, regardless of the state concerned: that is the old and standard uniformity idea, the product of and partial answer to the tension between state jurisdiction and national market. Here there is a further aspect of uniformity: the production of some reasonable theory of and approach to the problem of secured commercial financing as a whole, and the setting of the devices into an arrangement of internal order along some single line within each state as well as among the states. For on the business side, and on the banking side, financing is a whole. There would be value in having the legal devices built to fit the various business and banking needs which constitute that whole.

\section{II}

\section{Preliminary Functional Analysis}

When one turns now to examination of situation and need, in order to consider what patterns of legal transaction might be tailored to them, the first effect is to threaten despair over reaching any "simplicity." There is indeed a very welter of situations, with divergent and frequently contrary needs, hidden beneath this single label of "the secured commercial transaction." The present symposium, for instance, with all the complexities and variations which the various papers canvass or sug- 
gest, is still (except for McGowan's letter-of-credit paper) centered upon a single basic type of situation: (I) current financing of (2) a business by (3) fresh advances of (4) "money," (5) secured by "inventory" in the wider sense, i.e., including especially accounts receivable.

Each of the italicized terms suggests the presence of other and different situations which may and sometimes do present other and sharply divergent needs.

I. Thus current financing contrasts with permanent financing; when a bond issue secured by mortgage on plant is to be secured by an operating plant with a going-concern value, the problem of chattel equipment and its replacement comes into the picture, but with special legal problems such as those of fixtures, of duration, of "realty" publicity policy, of after-acquired equipment, of special protection for suppliers of new equipment (not "money" financing) needed to help out or bail out an enterprise which, though already mortgaged, has become a touch decrepit. And though Mr. Kupfer's paper shows this last problem to be partly paralleled in regard to "inventory," the parallel is exact neither on the business side nor on the legal.

2. Business financing, in turn, contrasts with the financing of purchase by the individual or family consumer, and with the financing of the non-corporate farmer. As to the latter, let me remind merely of crop finance (sugar beets, hops, lambs, wool, or cotton) with such double problems as covering the as-yet-nonexistent and yet preserving a basic policy against substantial peonage; or of the peculiar problems raised by share-cropping or other tenant farming. Again, as regards the individual or family consumer, is there not, these days, real reason to doubt whether publicity by filing serves any essential function, say for at least a year after purchase? Who can in reason, in a régime in which purchase of expensive articles on installments is notorious, claim to be a good faith purchaser of a second-hand article, from a non-dealer, without either seeing the bill of sale or receipted bill of his consumerseller (or the title-certificate) or consulting the dealer from whom the article was bought? The unpaid-for domestic furnace does stand on a different footing; but that is a question of realty record policy.

On the other hand, the domestic consumer-purchaser raises, as has been suggested above, problems with reference to safeguards on foreclosure. The Revised Sales Act has taken the position that on a conditional sale the security may not be extended to cover the unpaid price of other articles; the accompanying query is whether the same policy should not properly prohibit the inclusion of other articles in a "chattel mortgage" for a purchase price. And there are in a goodly number of states "protective" statutes dealing with installment purchase along a number of lines. Little as it may seem desirable to include such provisions in a commercial code, surely the arrangement of a code should be such as to harmonize comfortably with the presence of any such protective provisions in the particular area, wherever local policy calls for them. But they have no perceptible relation to the current financing of a business. 
3. Fresh advances as the subject of security must be contrasted-as is implicit in the conditional sale, and as is explicit in the Uniform Trust Receipts Act and in the proposed amendment to Section 60a-with the "preference" problem raised when security (or "goods"-"payment") is sought for old debts originally contracted with insufficient security or with none at all. It no longer needs argument that the two situations require different treatment (though the policy of the Negotiable Instruments Law appears to have frozen into what seems to me an anomalous and unhappy disregard of that fact).

What is less familiar is the problem partly discussed in this symposium by Mr. Kupfer: that of how long fresh advances on inventory, intended as current and (in an ambiguous phrase) as "self-liquidating," should be recognized in continuing priority when the advances have staled into complete actual failure to liquidate themselves. When advances are pressed as calling for peculiarly favorable consideration (as by Mr. Burman) because of a peculiar attribute-current "self-liquidation"-their claim may itself call for re-examination in the event that they fail to display the attribute in question. Against this possibility stands the argument that security exists to cover the very event of misfortune or misjudgment, and that many an enterprise can and will be "babied" along out of difficulty if the secured creditor's rights can be relied on during the period of indulgence. Or, indeed, if he can, against substantial fresh advances, obtain safe security for the whole "consolidated" indebtedness, including that previously unsecured-though on this last matter it can be argued with some cogency that the case for protecting the salvaging creditor in regard to old indebtedness rests indeed on a reason akin to that of salvage, and should in consequence be made dependent on success.

\section{III}

\section{Caveat on Views of Policy Here Suggested}

I hope it is obvious that I am not in this paper laying out or laying down or even foreshadowing the lines of policy which will in fact control the article on Secured Commercial Transactions in the Uniform Commercial Code. Even the proposed rough divisions of that Article are still tentative (e.g., domestic purchase, farm finance, inventory, equipment, pledge, bulk sales). And I have neither authority nor desire to prescribe the lines of eventual operation. There are draftsmen at work, there are advisers to advise and vote, there are experts and interests already extensively consulted, and further to be consulted; there are two great organizations whose Councils, Sections, and Floors have established habits and techniques of sane, hard-hitting criticism and revision of the Code proposals. In them lies the authority and decision.

What I am attempting to do is a very different thing. I am attempting to lay out some of the lines of problem which an Article on Secured Commercial Trans actions must face and solve, and to do some tentative exploration of considerations which present themselves as one searches for solutions. 


\section{IV}

\section{A Prospective Code and Its Divisions}

\section{A. The Uniform Commerical Code}

The lines of thought indicated above have led into the project for a Uniform Commercial Code. The law of Sales of course became the center, with such overlap into "agency" aspects of distribution as is needed to clarify the bona fide purchase and the security aspects that come in question. In general, the Revised Sales Act modernizes remedies, with special attention to furthering adjustments and to reducing the stake in dispute; it materially expands the coverage of the old Act, as by including overseas transactions and those bodies of conflicting case law which have developed under the old Act or in areas left untouched by it ("open" terms, the right to a receipt, buyer's right to inspection under "on arrival" terms, insulation of the banker by discount of documentary drafts, clarification of the installment and anticipatory breach problems, etc.), and it places the various issues between seller and buyer on the basis of the contract terms and the seller's actions, rather than on the question of when the title is to pass.

On the side of Commercial Paper, the many case-law conflicts have been cleared up, proceedings on dishonor simplified, obsolete material like acceptance and payment "for honor" eliminated, and current paper separated from investment securities, with bonds, share certificates and the like dealt with in a separate article. Bank collection has, however, been included in Commercial Paper, with new statutory regulation of the item-by-item collection typified by the documentary draft, and with the float of "cash items" (which have long come to be handled in bulk) dealt with by new law which recognizes both the banker's operating necessities and the interest of customer and community in turning oustandings into available current account credit with speed. Warehouse receipts and bills of lading are drawn together into a separate article, with slightly expanded coverage; the transfer of such documents is taken out of the Revised Sales Act. As a corollary to coverage of the overseas sales transaction, there has been coverage of its complements in banking practice, the letter of credit and the foreign remittance-the former being of course made available for domestic use as well; and where international banking practice differs sharply from domestic, need has been served and confusion dispelled by special regulation of the international.

This general regulation of overseas transactions would in itself require recanvass of the intricate Trust Receipts Act; and the trust receipt has also made its way into domestic finance. It opens up, moreover, the whole question of inventory finance, and inventory finance in the strict sense bridges at once into the problem of receivables. Indeed, for American business, a code seemed to lack its legs if security for current financing were not included. And if, as has been suggested above, there was in fact point in recanvassing the traditional legal devices, then consumer and farm finance (the final purchase which takes good out of commerce, making 
them goods rather than wares; and the growing of materials to enter into commerce as wares) -these called for canvass, too.

\section{B. Security: Preliminary}

Underlying all other problems in this last area is a question of policy raised no less by the financial history of our country than by the current unmistakable danger of over-inflation. The history has been a history of alternating boom and bust. I refer not merely to the business cycles common to the Western economy under capitalism, but to the peculiar American variant thereof: easy credit, entrance upon any type of enterprise by any quantity of persons regardless of their training or experience, lavish bankruptcy and waste of capital assets on a scale no other country has ever been able to afford (but with the emergence also of the self-made, forward-driving genius in field after field: Edison, Ford, Ittelson, Kaiser), andmost amazing of all when set against the European picture-the comeback of men who have already gone under once or twice or thrice-a comeback not only on Wall Street but in the operating fields. Of all this sequence, easy credit is the recurring causative factor, waste and financial calamity for all of us the one recurring consequence, while forward movement, for all of us, of the whole economy is the other. Planners may think the virtues of the easy-credit cycle have been worked out as the economy gets tighter, or that the costs rise and spread faster than the gains, or that a more reasoned and controlled arrangement can preserve or increase the gains with lessened costs.

Codifiers in the field of secured commercial transactions are not planners of an economy, they are but shapers of legal tools to be used at will. Yet a convenient, a serviceable tool bids for use. I can see no question that simplifying and opening to a wider portion of the bar the effective use of security devices is likely to spread their use; and no question that really opening up inventory as legally safe security will spread its use in that regard.

I cannot, however, as a person, feel that the policies underlying a code with a hope of half a century's use (such as the Negotiable Instruments Law has enjoyed) should be heavily affected by argument addressed to possible inflationary effects of easier credit during the now current shortage of materials, a shortage which has no prospect of lasting beyond another year or two. Code thinking must be longterm thinking; this is not a question of a current, temporary measure looking toward amendment by every other session of a legislature. And on the long-range side I as a person feel that the tendency of full legal availability of the assets of an enterprise to serve as security will expand net credit materially less than it will secure that credit; that its tendency must indeed be to make credit somewhat easier, but that the nature of inventory finance on the side of major probable expansionthat of the smaller business-is to introduce into the picture, along with some further credit, a lender's cautionary pressures of restraint. Neither American bankers nor American finance companies have been too good at this; and the illusion of "security", has often enough led into lending in first instance on things 
rather than on people and on enterprise, and with sad results; sound commercial finance cannot be done with a pawnbroker's eye or brain. Yet it seems to me clear that there has been over the last decades materially more financing judgment and materially more financing training abroad in the land than used to be the case; and it seems to me that any shifting from unsecured to secured credit means a solid step toward materially reducing the speed-and above all the speedy roll-up-with which financial calamity has, in the past, struck in.

There is no need to point out that in a situation like that of $193^{\circ}$ the matters suggested amount to a straw barrier against a flood, nor to point out that cautionary restraint fails easily when the borrower is big enough to make relations with "him" resemble wooing rather than advice. Yet I hold the balance of policy to look clearly toward expanding the availability of secured credit, provided that the borrower is protected in machinery for changing his financer, and that general creditors are protected from deception.

To date, the Code Article on Secured Commercial Transactions has been moving along those lines.

\section{Special Inventory Lien}

The first sustained center of attention has thus been the field of security in the current assets of a business. Aside from cash in till or "cash" in current account with a bank, the most nearly liquid of these assets is of course the receivables. Next in line is stock: the inventory of a merchant who buys for resale; the finished product of a manufacturer. Here, as with the "readily marketable staples" which used once so to interest the Federal Reserve Board in regard to rediscount, selling and delivery remain still to be done; whereas with the receivable, in theory and dominantly in practice, only collection remains, the controlling economic risk is that of debtor default-though an adverse turn in general conditions or the particular market can precipitate an unpleasant drizzle of unwarranted claims for breach of warranty. Still farther down the line are the manufacturer's or processor's raws and fuel, capable today of special financing on trust receipt (leather, fibers, green coffee) or even by field warehousing, but losing their "identity" and sacrificing sẹcurity as they move into "process."

For business purposes one has here a dozen different situations, with further subdivisions according to whether a dealer or wholesaler is stocking individual articles of relative durability and high price (cars, refrigerators, "hards," in general) or more general types of merchandise (say, groceries, or the general run of department-store goods); according to whether the production is essentially seasonal, with an expected seasonal clean-up; according to whether sales go to men: in the trade or to consumers; according to whether receivables take the form of open accounts or of chattel paper, and in either case according to whether collection is to be by the financer or by the borrower; according to whether inventory proper is financed in and for itself, as often enough in canning, or only as an adjunct to receivables financing, as commonly enough in textile factorage; according to whether advances 
are in essence specific ("sale" of accounts; release-price floor-planning of "hards") or are in essence a general percentage advance against a mass or batch of security items. And the first technical problem is whether there can be developed any relatively simple set of basic legal patterns which can meet the essential needs of such a welter of variant practice-not only the need for resilient but effective security, but also the need for manageable cheapness of operation and of legal work. Codification must bear in mind also that there are two types of financer: the outfit which builds up a customer and a business, and the outfit which loots both. The first and its work must be served, in any event; at the same time the second and its ravages must be hindered when that can be made consistent with service to the first. This has remained a problem since security devices were first invented.

In reaching for a functional division of material the first type of transaction which suggests itself is that branch of present trust-receipt finance illustrated by floor-planning. The articles are new, identifiable, and commonly capable of realization at a reasonable figure without reference to that going-value aspect of the borrower's business which constitutes one vital asset of a business under "general" lien, and is also an important element in adequate realization on a "general" stock in hand. Foreclosure by taking possession and by sale in any commercially reasonable manner is here feasible and fair. Moreover, "release-price" practice offers a lead in regard to how a neglected general creditor may be offered a simple wherewithal, without disruption of the business, to enforce his unpaid claim. One may note, finally, that in this fundamental phase of the business the simple, central, general-notice type of filing required by the Trust Receipts Act has met the approval of financers. (One must add that few inquiries are made at the filing offices. But one notes also that, in those lines of business in which such financing is now in use, the practice of so financing is notorious, whereas any general spread of inventory finance will be moving into new fields, and moving not universally, but enterprise by enterprise, thus introducing real problems in regard to letting unsecured creditors know where they stand.)

Such cheering simplicity of this type of functional specific lien is threatened along a number of lines:

I. Lenders, believing that the Trust Receipts Act failed to put into adequate language its policy of limiting the lien to the advance against the particular goods, have been attempting to spread that lien to cover other indebtedness. Even if (as I believe) this is prohibited by a sound construction of that Act, it will be urged as desirable to authorize, at least so far as concerns other indebtedness of the same character-other indebtedness, that is, which has financed the fresh acquisition of other like inventory. A compromise position here, so far as concerns policy, might recognize the "spread" coverage in liquidation, but until general liquidation (whether by the financer or of the business) might allow a levying or attaching creditor to reach the interest above the release price on any specific article. But how such a policy could be technically implemented by a state statute, in view of the Bankruptcy $A c t$, is another and plenty puzzling matter. 
2. The question can also be raised whether the wise functional division is "acquisition of fresh inventory" or "fresh advances." The former does have the virtue of assuring that the advances go into the business; it has also some virtue in holding down over-expansion of credit, in that acquisition of fresh inventory will in the main be financed only when the prospect of its resale is good.

3. Whether proceeds of goods held under such a lien take the form of plain receivables, or (as with sales to consumers) of chattel paper, or of "cash" received by the borrower, further problems arise. With regard to "cash" I have myself never been able to get away from so much of the policy of Benedict $v$. Ratner as insists that a financer must choose between acting like an unsecured lender and maintaining his security rights: i.e., that he must on pain of loss of such rights do reasonable policing to get in the ultimate proceeds at reasonable intervals. But I have not myself seen any reason why such a policy should require such interstitial steps as assignment of receivables or the turning over of chattel paper-each of which seems to me to involve unnecessary formality. On the other hand, a goodfaith purchaser of either receivables or chattel paper ought, as I now see it, to defeat pro tanto the original inventory lien of one who leaves those interim proceeds in his debtor's hands. And at this point the question arises whether some type of simple, central general-notice filing may not have value with reference to these types of proceeds quite as much as with reference to the inventory out of which they arise.

\section{Receivables and the Publicity Question}

Indeed, this may be as good a place as any to pick up that hottest of potatoes, the matter of publicity requirements in regard to the assignment of book accounts"receivables."

This is a question on which most interested persons took fighting positions some five years back. It seems to me that the positions have been submerged in the fight, to general misfortune, and that the battle, on the practical level of effective legislation, is close to a stalemate. Surely it is time for men who have stopped thinking on this matter to start thinking again. It will take effort, as is always the case when a lively fight has been under way. Even Mr. Burman's reasonable and wise paper, to take a single instance, becomes brusque, arbitrary, irritable, on a single point: publicity in the matter of receivables. That is the way all of us have gotten, over these years of pitched and guerilla warfare.

But I do suggest that most of the arguments in use on both sides of the matter can do with reconsideration.

I do not, for instance, see that central general-notice filing of the type envisaged by the "pro's" for receivables assures to general creditors (bank, merchandise, or other) the quick, sure information which its advocates seem to assume. In the first place, the credit services are not yet built to catch and distribute the information; in the second place, with any considerable spread of the practice of financing receivables, that spread (like any similar spread of inventory financing) is going to 
be into business of local character, with at least one large class of local creditors who are more than likely to have no effective access to central files. It is indeed probable that if legal provision should be made for both inventory financing and receivables financing, generally, and if both were put on a general-notice-filing basis, then the tradition of following the chattel files would join with the horse-sense of following a new development to produce what we do not as yet have: to wit, relatively easy and speedy access, for any creditor, to the information. But that is prophecy, not fact.

Somewhat similarly, the degree to which merchandise creditors are affected in their actual contracting and deliveries by knowledge of the existence of a lien on inventory or receivables or both is as uncertain a territory of human behavior as there is. We know that they squawk if such a lien shows up when bankruptcy has occurred; but how far they would really curtail seemingly profitable credit because of advance knowledge of such a lien is quite unknown.

On the other hand, the common arguments against general-notice filing likewise collapse on examination. For instance, the borrower's fear that he will lose status and suffer competitive disadvantage if his resort to receivables financing becomes public is hard to rime with the anti-notice partisan's insistence that no one is misled, anyhow, by secrecy of the lien, because the borrower's financial statement displays the financing; nor does the basis of that fear-which once was solid-survive the modern legitimacy of receivables financing ("Done by the best bankers"), as is demonstrated by experience in those states which already require notice filing.

There is no point in going on. We have an artificial and unpersuasive "standard" case on each side, leading, as I personally see it, to a simple set of basic issues:

I. In regard to any type of security whatever, given for old indebtedness, is not some kind of publicity desirable, if practicable, so as to warn the unpreferred creditors that the four-month period has begun to run? I should like to find a way of including here transfers of negotiable paper, and of warehouse receipts.

2. In regard to new-money financing, what difference does the kind of security make, in regard to the desirability or undesirability of any publicity? Should not all types of security move in that respect, so far as practicable, onto a single basis? If "simple validation" by the transaction itself is to be good for receivables, I see no reason in sense why it should not be good for inventory. Certainly our historical practices show no such reason, and if the borrower's financial statement can be trusted to do all the work needed for other creditors', or for purchasers', protection, I am for trusting it the whole way. So also and on the other hand, if some type of filing notice is to be used, I am for having a single resort to the file give reasonable indication of all the types of current assets which are not to be relied on by the inquiring creditor or prospective creditor or not to be bought by some new financer. I repeat that I should aim to put on a single footing every type of asset I could find means to: again with negotiable paper and warehouse receipts coming in for special study. 
Such an approach, I fear, makes too much horse-sense to find approval anywhere. But it does afford a base-line for resolving doubts when some choice must be made. Thus far, I find the balance of convenience and probable utility to incline toward spreading a system of simple, central notice filing as far as feasible. That can be accomplished with no burden on the great run of honest business. It provides the wherewithal for material reduction of the hole-and-corner double financing which does go on around the fringes of the business. Much more important for Code thinking: such a system moves comfortably forward into a general régime of inventory and "proceeds" financing. If such financing really spreads (and I have indicated that I feel it should and will), the historic opposition to secret liens has two messages that cannot be disregarded. The first message is that in the course of such a spreading out of the financing type there will be enough smart guys pulling enough fast ones to stir up enough resentment to kick legislators into some kind of preventive or repressive legislation. Receivables can expect to live on no magic island of refuge from such an atmosphere. The second message is that that kind of resentment-reform is with some inevitability half-baked, unduly restrictive of legitimate operations, uneven by area of law and area of country, unstable, and generally unhappy in result. The way to avoid a spasmodic hodgepodge of such resentment-reform is to build a sane and feasible over-all scheme which cuts to a minimum any resentment which even the over-wily have room to arouse.

But in the present state of interested and organized opinion, we have in this emotional division on the matter of publicity the major headache incident to codifying the law of current financing.

\section{E. General Inventory Lien}

A wholly different general type of lien is suggested by the chattel mortgage on the stock in trade, or by the floating charge familiar in Canada, or by the birth-todeath type of security sought where raws are trust-receipted into a manufacturer's hands, finished goods placed under a statutory factors' lien, and deliveries made on a "factored" account, or, finally, where raws are "bailed" by a prospective "buyer" and the "sale" is put more or less into the form of a work-and-labor contract.

Viewing the matter purely as one of security for current financing, the historical restrictions on security of this general type seem absurd, provided only that deception about ownership is avoided. That is, the combination of trust receipt and factors' lien under statutes each of which requires a due public warning would in this view be unobjectionable-indeed the urge would be to do away with the present uncertainty about goods in process and all the irrelevancies of confusion, accession, or even (where only one lienor is concerned) of identification, and to set up instead a single over-all general lien on current assets; while the bailment-for-work-and-labor set-up would come in for study chiefly on the side of publicity requirements: the line to be drawn would for instance not bother goods in the hand of a processor known to be in the business of processing for others (say, a tanner, a throwster) but would require publicity in the case of a parts manufacturer working exclusively 
for a prime manufacturer on materials "bailed" by the latter for the purpose; and the problem would be to develop both sense and definiteness in the more exact drawing of such a line. Notice-publicity should be requisite to protect a bailor-buyer who is in essence even more of a merchandise financer than is, for instance, one who supplies equipment on conditional sale.

This "simple-security" approach proves, however, less simple as one explores its ramifications. What of proceeds? There is a "simple" conceptual appeal in the idea that since no proceeds are specific to a general lien for 50 or 60 per cent of cost, the lien should, short of general liquidation, be limited to the goods as such. The price of obtaining the pervasive goods-lien, freed of all technical complications, would then be to leave free for general creditors all proceeds (receivables, chattel paper, "cash") which might be in the hands of the borrower when general liquidation opened. This would work also a sort of rough equity as between a financer who took the pains necessary to procure and maintain a specific inventory lien and one who rested content with an unpoliced general float. But against such an approach it is argued that every dollar made available out of proceeds lifts that much burden off the inventory and thus furthers maintenance of the going value of the business, for the benefit of all. This latter line of argument, of course, leaves unsolved the problem of the neglected general creditor and of giving him some machinery (short of forcing bankruptcy) for enforcing payment of his claim. The obvious way-to leave proceeds open to levy, until general liquidation has set inruns into the technical difficulties already mentioned above in regard to special inventory liens.

Granted any legal recognition of this general type of lien, no reason appears for any of the particular and detailed technical requirements which have been set up as conditions. For instance, after-acquired inventory should flow into coverage by mere initial description and later acquisition, with no heed to the doctrine of the "new intervening act" of appropriation (although of course purchase-money financing by way of specific lien should remain possible). And the Benedict $v$. Ratner aspects of policing, however wise in practice, leave me unpersuaded as to their value as flat conditions to legal validity except (if proceeds be included in the lien) with respect to ultimate proceeds. Again, as already indicated, I see no trouble and some gain from letting the lien reach a manufacturing borrower's goods in process.

But in each of such restrictions, however unfounded each may be in itself, and in their variety and cumulation and pervasiveness, lies a warning. Gropingly but persistently, men in this country have been bothered about this type of lien. And at least one member of the Code drafting staff continues to be thus bothered. The older worry over secrecy can indeed be met in the run of "real business" cases by publicity, by simple general-notice filing. But if poppa-and-momma stores are going to be open to this type of lien, and in favor of relatives and friends, then those worries arise again to plague us which have led over past centuries to the law of 
"apparent ownership," of "hindering creditors," of "sleeping partners." Speculations therefore proceed to float through my mind, about possible limitation of the general lien on inventory-or indeed on receivables-to a financer who is "in the business" of financing; and other speculations about whether businesses of certain descriptions ("single location" or "less than blank thousands of assets" or "wholly located within a single county" or what else or better?) should not call for local filing publicity in addition to the normal central state filing.

That is one line of bother, and it is associated with the type of indebtedness which ought to be open to be secured by any such general lien. One thinks in terms of fresh advances, present or future, flowing into the uses of the enterprise: current financing. One runs into immediate trouble if the advances do not in fact so flow, but are diverted; one runs into trouble with the "bail-out and consolidation" situation discussed earlier, where a lender theretofore unsecured is ready to step in with material new advances, but only if his, whole indebtedness can be effectively secured.

The other line of bother cuts as deep, but cuts in another quarter. This type of financing, from the days of early capitalists' "putting-out" of work through the days of the first Ford's squeezing of his suppliers, with echoes in sugar beets, the fisheries, lumber, garments, and what have you more-this type of financing (especially but not exclusively by a "buyer") lends itself with curious ease to the development of industrial peonage. And it is not pleasant to contemplate responsibility for furthering, shaping, perfecting and polishing a device which invites use to that end. For as observed above: neat devices do invite, they do encourage, use. My feeling runs clearly, however, to the proposition that the general inventory lien, as a device, can be healthy in so many instances, in so many types of instance, that it warrants working out into smooth operation. This is a case in which I should hope to see abuse, if it develops to the point of resentment-reform, channel men's thinking into the lines of the particular industry or trade which makes the abuse appear, rather than into the lines of the legal devices being used; so that restrictive legislation might be directed not to the security device as such, but to its abuse in particular lines of circumstance.

\section{V}

\section{ConcLusion}

Thus it seems to me that on the side of inventory and receivables financing there are lines of major pattern which do open and offer some promise of effective functional reorganization and simplification of security devices. I should assume that those same lines would work, with minor modification, for equipment financing; the major special need found with this last would seem to be to develop a convenient means for mortgaging equipment and replacement (whether fixtures or other) in conjunction with a mortgage on plant. I should assume that consumer lien and farm financing, on the other hand, would offer other and independent 
problems. On the farm side the relatively recent federal-inspired "wave" of farmer's chattel mortgage legislation offers an initial base-line, with need also to look into "barn-warehousing." On the consumer side, I take it that purchase-money financing represents one major and separate type. In regard to such purchasemoney liens, the present trend of the Code's drafting is strongly in favor of freeing the transaction, for a year, from any filing requirement, and also of limiting the lien to the chattel sold; a result which would allow convenient consolidation of all the types of purchase-money lien now in use. A simplified but satisfactory foreclosure procedure would seem to be materially easier to build when such "business" articles as equipment are taken care of as such, leaving the consumer picture free of complication. Finally, in the field of motor vehicles it seems to me clear that the Code should seek to work in harmony with the best title-registration statutes and practice.

But of course, in all these matters, personal views remain personal. The staff and the controlling organizations go their way, sometimes persuading the individual that he is wrong, sometimes overruling him, never controlled by him.

Hence the only matter on which I can state an official position is this: that the effort to reorganize, simplify, and modernize the field of chattel security does appear to be worth while, and that the further aid of businessmen and lawyers in the field will continue to be as welcome in the future to the staff of the organizations as that aid has been in the past. 